\title{
SIMULATION OF RIVER DISCHARGES IN MAJOR WATERSHEDS OF NORTHWESTERN JAVA FROM 1901 TO 2006
}

\author{
Miga M. Julian ${ }^{1 *}$, Fumihiko Nishio ${ }^{2}$, Poerbandono ${ }^{3}$, Philip J. Ward ${ }^{4}$ \\ ${ }^{1}$ Study Program of Geodesy and Geomatics Engineering, Institute of Technology, Bandung 40132, \\ Indonesia \\ ${ }^{2}$ Center for Environmental Remote Sensing, Chiba University, Chiba, 263-8522, Japan \\ ${ }^{3}$ Faculty of Earth Sciences and Technology, Institute of Technology 40132, Bandung, Indonesia \\ ${ }^{4}$ Institute for Environmental Studies, VU University Amsterdam, De Boelelaan 1085, 1081 \\ HVAmsterdam, The Netherlands
}

(Received: November 2010 / Revised: December 2010 / Accepted: January 2011)

\begin{abstract}
This study is intended to simulate the river discharges in major watersheds of northwestern Java, Indonesia. The five largest watersheds are considered: Ciujung, Cisadane, Ciliwung, Citarum, and Cimanuk. The simulation period covers the $20^{\text {th }}$ century and early $21^{\text {st }}$ century, from January 1901 to June 2006, at a monthly time step. Discharge simulation was carried out using STREAM (Spatial Tools for River Basins and Environmental and Analysis of Management Option). The input data for the simulation are climate (precipitation and temperature), land cover and topographic data. Setup and analysis of input data are also part of this study. The Mann-Kendall test and linear regression were used to detect trends. Temperature datasets show statistically significant increasing trends for all periods and areas. Significant increasing trends of precipitation occurred in the latest 16-year period (1990-2006) in hilly and middle areas. A positive trend of simulated discharge is seen in all watersheds and periods. They are only significant for Ciujung (periods of 1950-2006 and 1975-2006), Cisadane (periods of 1950-2006 and 1990-2006), and Ciliwung (periods of 1950-2006, 1975-2006, and 19902006). The most noteworthy trend is seen in the 1990-2006 period. Over the course of the $20^{\text {th }}$ and early decade of the $21^{\text {st }}$ century, monthly discharges have increased by $3 \%$ to $9 \%$.
\end{abstract}

Keywords: Climate; Discharge; Land cover; Simulation

\section{INTRODUCTION}

Changes in climate and land cover are currently taking place globally. In the $20^{\text {th }}$ century, averaged air temperatures recorded in Jakarta (Poerbandono et al., 2009a) increased by at least $1.2^{\circ} \mathrm{C}$. Consecutive conversions of forest cover to agriculture and residential areas have resulted in the waterproofing of soil, leading to a decrease in infiltration rates, thereby causing fresh water to discharge more rapidly to the sea. This means that the water residence time in the basins is decreasing, and that fresh water availability is diminishing. Decreasing availability of fresh water is an indication of the degradation of environmental quality.

In this study, we intend to simulate river discharges using a calibrated spatial model. The period of simulation covers the $20^{\text {th }}$ century and early $21^{\text {st }}$ century, from January 1901 to June 2006, at a monthly time step.

\footnotetext{
${ }^{*}$ Corresponding author's email: miga.m.julian@gmail.com, Tel. +62-22-2530701, Fax. +62-22-2530702
} 
The study area is located in northwestern Java, Indonesia (Figure 1). Ciujung, Cisadane, Ciliwung, Citarum, Ciliwung, and Cimanuk watersheds were investigated. The final outlets of all of the watersheds are located in the southwest Java Sea.

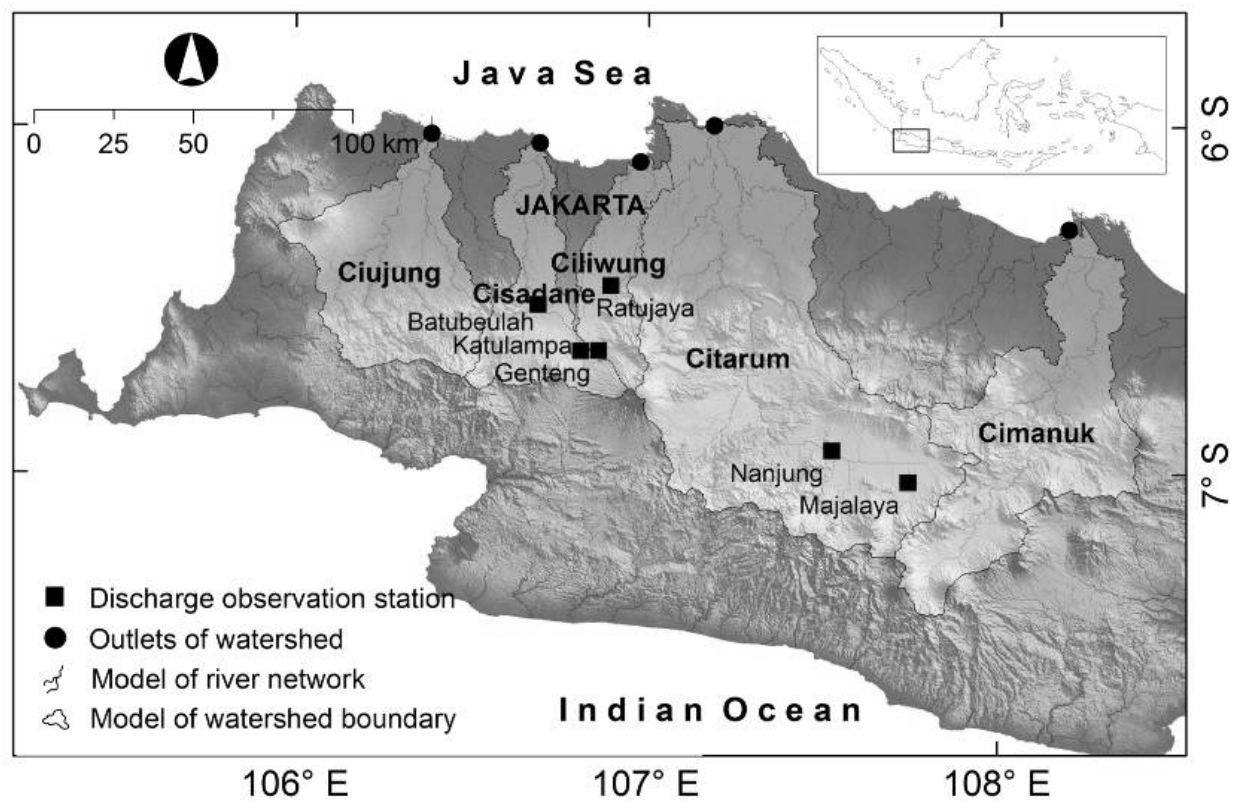

Figure 1 Study site

In a previous study, the calibration, simulation, and application of the model used here were successfully carried out and documented (Poerbandono et al., 2009a; Poerbandono et al., 2009b; Julian et al., 2009a; Julian et al., 2009b; Poerbandono et al., 2009c). The previous research covered a 102-year period (from January 1901 to December 2002) and applications were carried out at a low spatial resolution (i.e., $1 \mathrm{~km} \times 1 \mathrm{~km}$ ). In this study, we applied STREAM at a higher resolution (i.e., $100 \mathrm{~m} \times 100 \mathrm{~m})$ and for a longer period (106-year period).

\section{MATERIALS AND METHOD}

In this study, the simulation of discharge was performed using STREAM (Spatial Tools for River Basins and Environmental and Analysis of Management Option) (Aerts et al., 1999). STREAM is a raster-based spatial tool and calculates the water balance per time step. STREAM describes the hydrological cycle of a drainage basin as a series of storage compartments and flows. STREAM applies Thornthwaite-Mather's water balance approach (Thomthwaite \& Mather, 1957) to calculate flow discharges along river networks derived from a digital elevation model (DEM). The main inputs of the model are climate data (maps of precipitation and temperature), a DEM, and land cover maps.

STREAM has been successfully calibrated and documented (Poerbandono et al., 2009b). The calibration considered discharge observations from six stations located mostly in the upper parts of the watershed (Figure 1). According to Poerbandono et al. (2009b), the corresponding correlation coefficient $(r)$ ranges between 0.72 and 0.93 . The computed mean annual discharge in five out of six stations is within an average of $7 \%$ above and below the observed discharge.

The Mann-Kendall test was used to detect trends in the annual series (Xiong \& Guo, 2004). In addition, linear trends are used to quantitatively describe the possible linear trend in the time 
series of the input data and simulated discharges. Several data are required to simulate the hydrological process with STREAM; here we considered a DEM, precipitation and temperature data, and land cover data. A DEM was used to derive the river network model and for watershed delineation. In this study, the 30m ASTER global DEM (GDEM) was used. The model of the river network and watershed boundary generated from ASTER GDEM shown (Figure 2). The area of modeled watershed boundaries is also provided (Table 1).

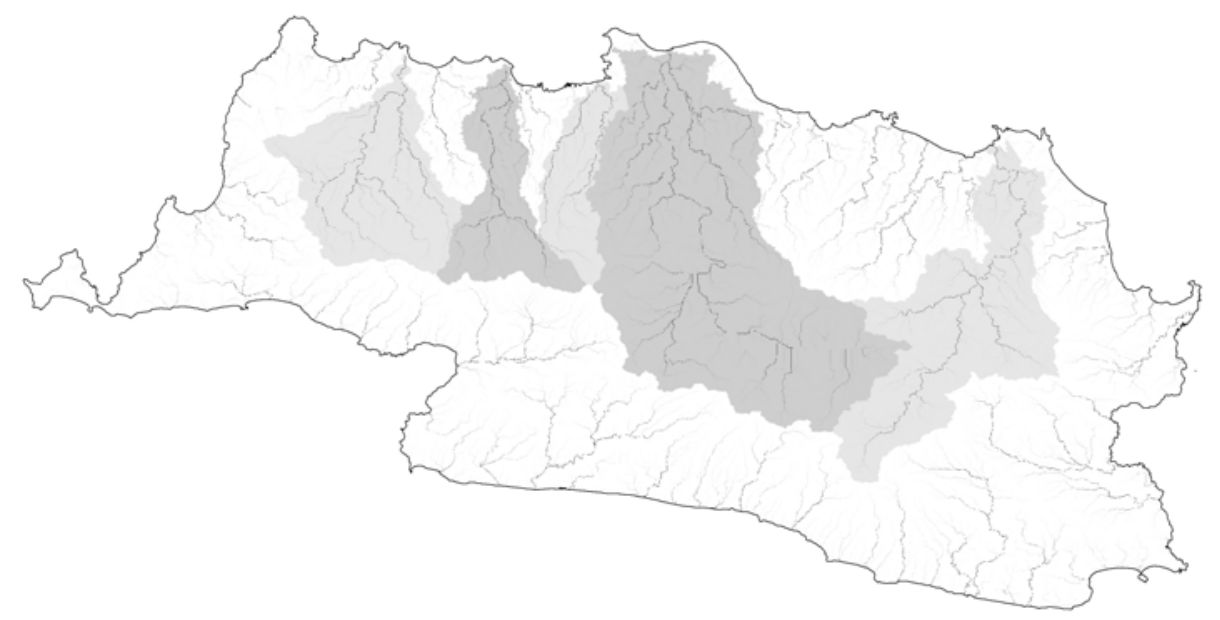

Figure 2 Model of river network and watershed boundary in northwestern Java

Table 1 Area of modeled watershed boundaries

\begin{tabular}{|c|c|c|c|c|c|}
\hline & Ciujung & Cisadane & Ciliwung & Citarum & Cimanuk \\
\hline Area $\left(\mathrm{km}^{2}\right)$ & 2809 & 1726 & 1147 & 8058 & 4013 \\
\hline
\end{tabular}

Precipitation and temperature data were retrieved from the Climate Research Unit (CRU), University of East Anglia, United Kingdom (CRU, 2008). CRU provides precipitation and temperature datasets at a monthly time step from January 1901 to June 2006 at a 30 arcminute $\times 30$ arc-minute spatial resolution (CRU TS 3.0). The CRU TS 3.0 dataset was downscaled to a 10 arc-minute $\times 10$ arc-minute spatial resolution. Figure 3 shows the annual average downscaled temperature datasets. Pixels located in Nanjung (representing a hilly area), Ratujaya (representing a middle area), and the outlet of the Ciliwung watershed (represented as coastal area) (see Figure 1) were evaluated. It can be seen that the average temperature has increased dramatically. A summary of linear trends in the temperature datasets is given (Table $2)$, and all show positive trends. Temperature datasets show statistically significant increasing trends in all periods and areas $(\alpha=0.01)$.

Table 2 Linear trend of temperature datasets

\begin{tabular}{ccccc}
\hline \multirow{2}{*}{ Location } & \multicolumn{4}{c}{ Trend $\left[{ }^{\circ} \mathrm{C} /\right.$ year] } \\
\cline { 2 - 5 } & $1901-2006$ & $1950-2006$ & $1975-2006$ & $1990-2006$ \\
\hline Hilly & 0.01 & 0.02 & 0.02 & 0.01 \\
Middle & 0.01 & 0.01 & 0.02 & 0.01 \\
Coastal & 0.01 & 0.02 & 0.02 & 0.01 \\
\hline
\end{tabular}




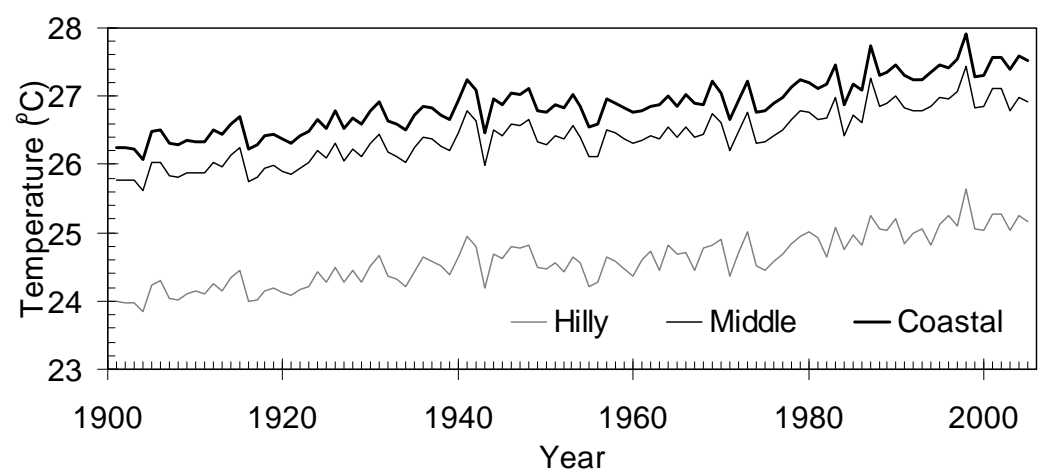

Figure 3 Annual average of temperature datasets in hilly, middle and coastal area of northwestern Java

Based on annual averages of the precipitation datasets (Figure 4), linear trends in the precipitation datasets for various periods are summarized in Table 3. Except for the coastal zone, positive but not significant linear trends were observed for the 1901-2006 period. Significant increasing trends of precipitation occurred in the latest 16-year period (1990-2006). They are only statistically significant for hilly $(\alpha=0.01)$ and middle areas $(\alpha=0.05)$.

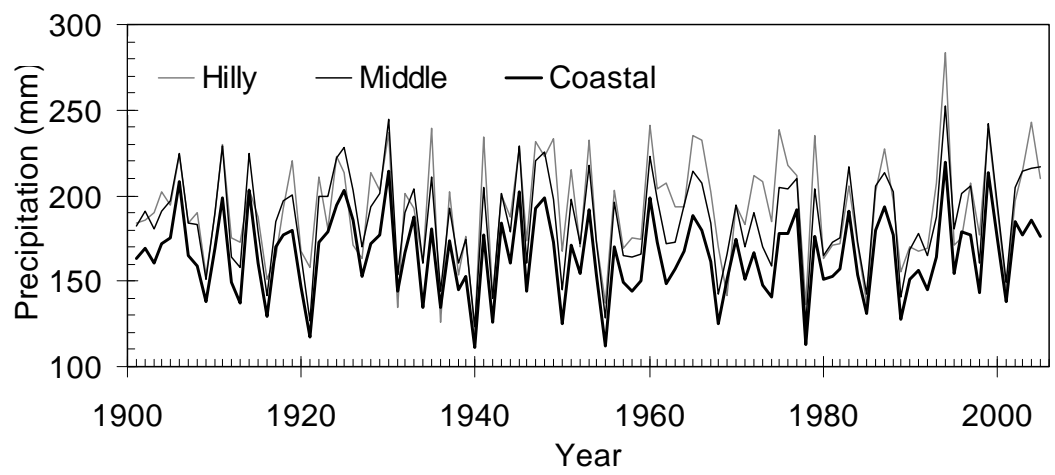

Figure 4 Annual average of precipitation datasets in hilly, middle and coastal area of northwestern Java

Table 3 Linear trend of precipitation datasets

\begin{tabular}{lcccc}
\hline \multirow{2}{*}{ Location } & \multicolumn{4}{c}{ Trend [mm/year] } \\
\cline { 2 - 5 } & $1901-2006$ & $1950-2006$ & $1975-2006$ & $1990-2006$ \\
\hline Hilly & 0.09 & 0.14 & 0.44 & 1.90 \\
Middle & 0.04 & 0.42 & 0.77 & 1.99 \\
Coastal & -0.01 & 0.33 & 0.49 & 1.32 \\
\hline
\end{tabular}

Land cover maps for various years and classifications, and from various sources, were used for the simulation period (Table 4). Land cover maps were generalized according to the water holding capacity of the soil (WATERH) and a crop factor coefficient (CROPF) used to calculate actual and potential evapotranspiration (Poerbandono et al., 2009a; Kwadijk, 1993). Figures 5 and 6 show the time series of spatial averages for CROPF and WATERH. Low values of CROPF and WATERH are noted in the Ciliwung watershed. Significant reductions of 
WATERH and CROPF are noted in the latest decade of the simulation period, as a result of reduced forest covers.

Table 4 Historical land cover maps

\begin{tabular}{cllr}
\hline No. & \multicolumn{1}{c}{ Title of map } & \multicolumn{1}{c}{ Source } & Year \\
\hline 1. & Natural forest cover of Java & (Whitten et al., 1996) & 1891 \\
2. & Vegetation of Indonesia & US Department of Forest Service & 1950 \\
3. & Land use map of Java and Madura & FAO & 1963 \\
4. & Land use map & Ministry of Interior Indonesia & 1980 \\
5. & Natural forest cover of Java & (Whitten et al., 1996) & 1987 \\
6. & MODIS land cover type product & (ORNL DAAC, 2001) & $2001-2006$ \\
\hline
\end{tabular}

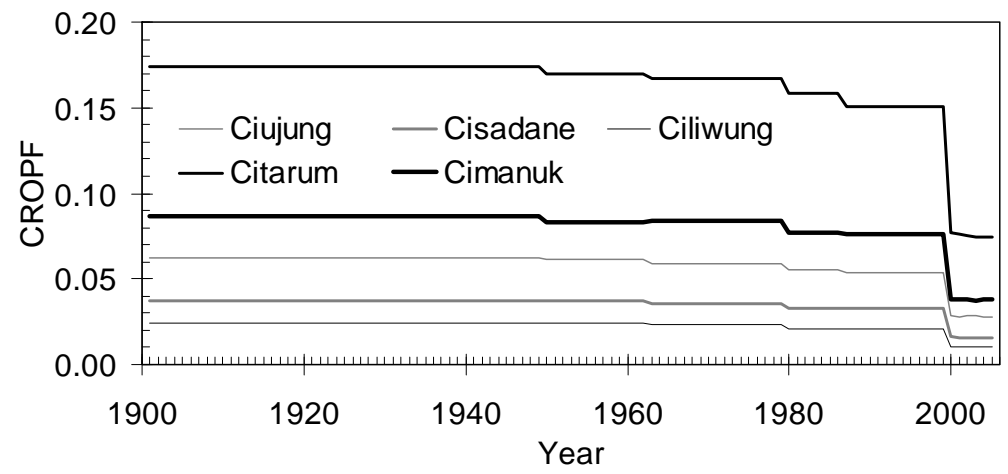

Figure 5 Time series of spatial average of crop factor (CROPF)

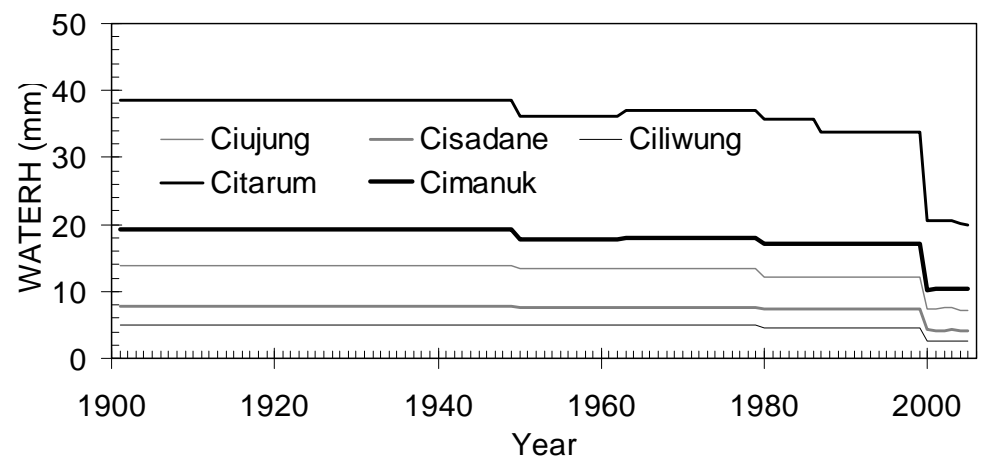

Figure 6 Time series of spatial average of water holding capacity (WATERH)

\section{RESULTS}

River discharges were simulated at a monthly time step from January 1901 to June 2006 (see Figure 7 for annual average simulation results). Table 5 provides statistics of simulated discharges for each watershed for the entire simulation period. Citarum and Cimanuk watersheds contribute the most fresh water to the Java Sea. Positive linear trends of simulated discharges are seen in all watersheds and periods (Table 6). Table 7 summarizes results of the Mann-Kendall test to detect increasing trends of simulated discharges, which are only statistically significant for Ciujung (periods of 1950-2006 and 1975-2006), Cisadane (periods of 1950-2006 and 1990-2006) and Ciliwung (periods of 1950-2006, 1975-2006, and 1990-2006). The most noteworthy trend is seen in the 1990-2006 period. 


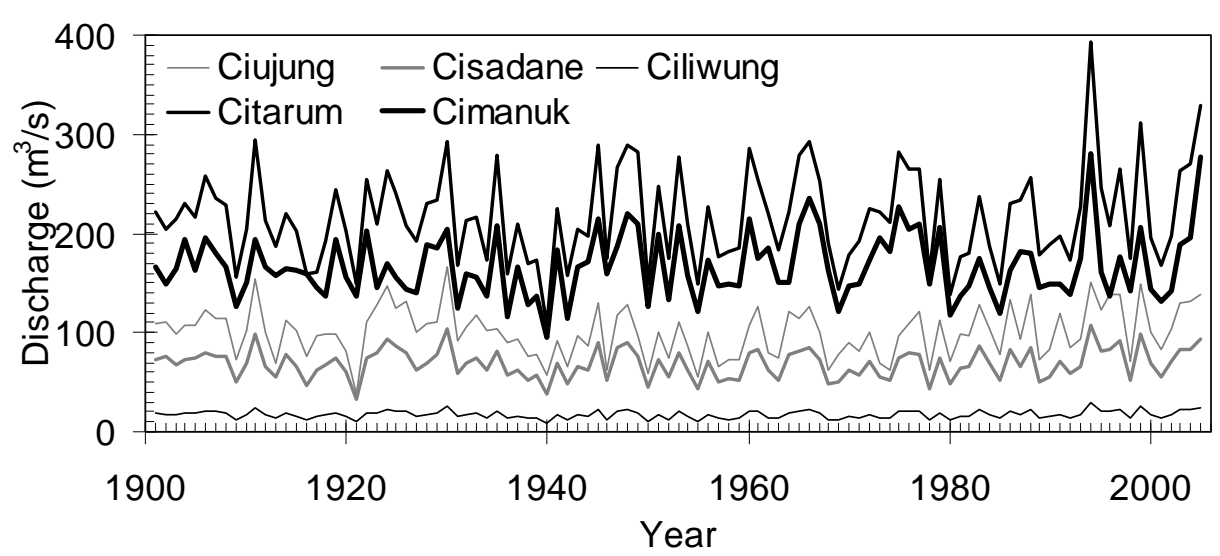

Figure 7 Annual average of simulated discharges

Table 5 Statistics of simulated discharges (in $\mathrm{m}^{3} / \mathrm{s}$ )

\begin{tabular}{lccccc}
\hline & Ciujung & Cisadane & Ciliwung & Citarum & Cimanuk \\
\hline Minimum & 16 & 12 & 3 & 36 & 29 \\
Maximum & 416 & 240 & 76 & 819 & 651 \\
Average & 101 & 69 & 17 & 218 & 168 \\
\hline
\end{tabular}

Table 6 Linear trend of simulated discharges

\begin{tabular}{lcccc}
\hline \multirow{2}{*}{ Location } & \multicolumn{4}{c}{ Trend $\left[\mathrm{m}^{3} / \mathrm{s} /\right.$ year $]$} \\
\cline { 2 - 5 } & $1901-2006$ & $1950-2006$ & $1975-2006$ & $1990-2006$ \\
\hline Ciujung & 0.04 & 0.70 & 0.92 & 1.38 \\
Cisadane & 0.02 & 0.33 & 0.50 & 0.94 \\
Ciliwung & 0.01 & 0.10 & 0.13 & 0.25 \\
Citarum & 0.19 & 0.60 & 1.33 & 3.18 \\
Cimanuk & 0.13 & 0.18 & 0.34 & 2.67 \\
\hline
\end{tabular}

Table 7 Mann-Kendall test results of the increasing trends of simulated discharges

\begin{tabular}{lcccc}
\hline \multirow{2}{*}{ Location } & \multicolumn{4}{c}{ Level of significance $(\alpha)$} \\
\cline { 2 - 5 } & $1901-2006$ & $1950-2006$ & $1975-2006$ & $1990-2006$ \\
\hline Ciujung & NS & 0.01 & 0.1 & NS \\
Cisadane & NS & 0.05 & NS & 0.1 \\
Ciliwung & NS & 0.01 & 0.1 & 0.1 \\
Citarum & NS & NS & NS & NS \\
Cimanuk & NS & NS & NS & NS \\
\hline
\end{tabular}

NS: not significant

Figures 8 to 12 show the 20 -year monthly average discharges of each watershed. From the magnitude of discharges, we can see that higher discharges occurred from October to March. Lower discharges occurred from April to September. Except for Cimanuk, comparing the solid 
thin line (1961-1980 period) to the solid bold line (the latest 20-year period), the discharges have increased by $3 \%$ to $18 \%$. Higher increases are usually seen in April.

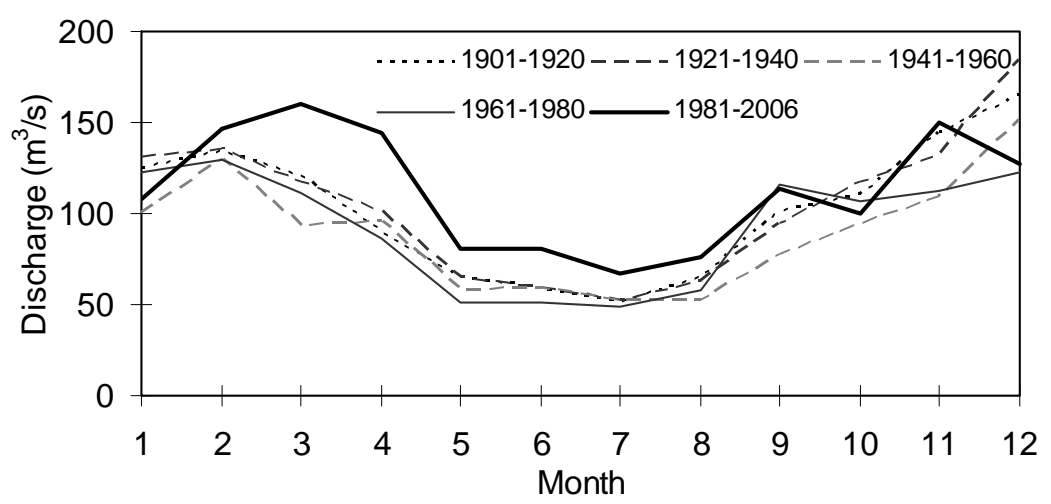

Figure 8 20-year monthly average discharges in Ciujung watershed

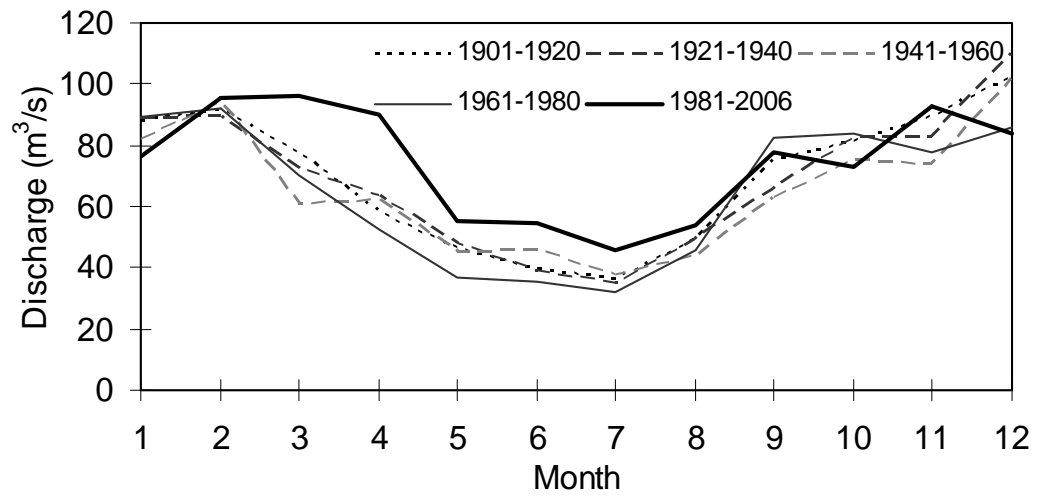

Figure 9 20-year monthly average discharges in Cisadane watershed

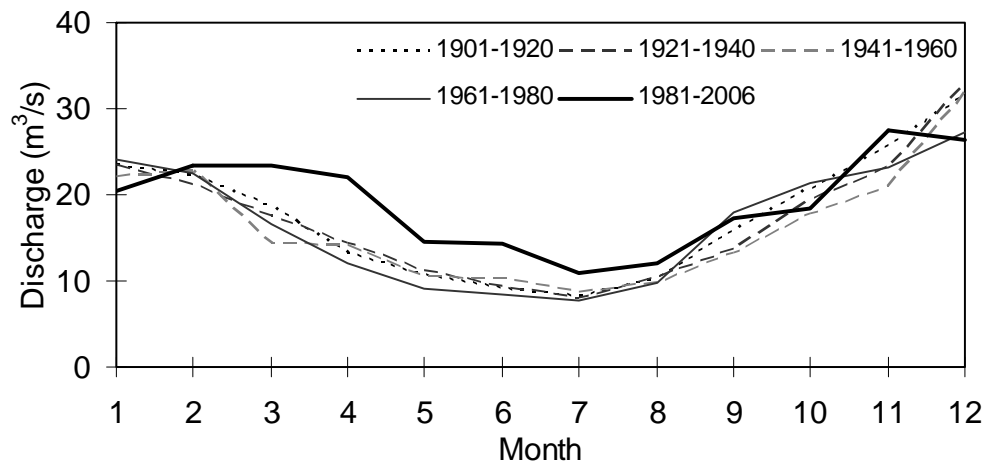

Figure 10 20-year monthly average discharges in Ciliwung watershed 


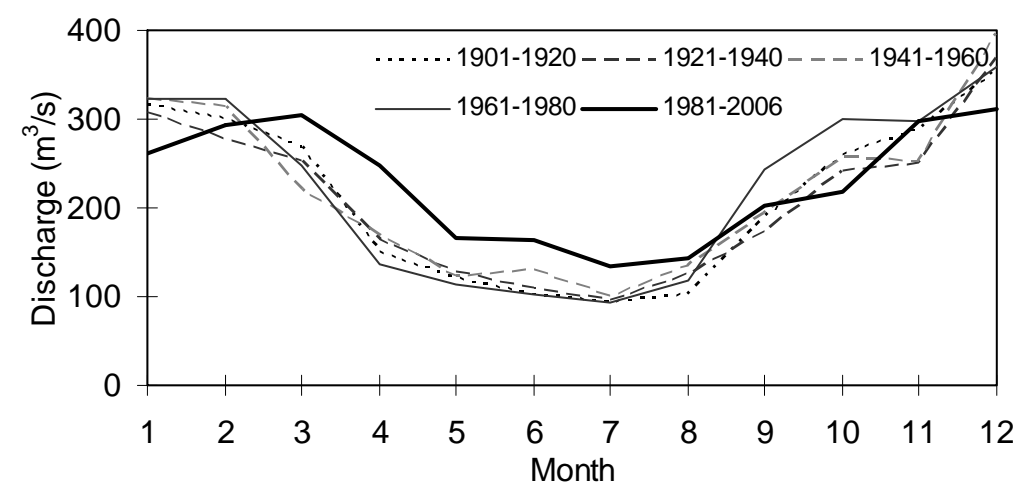

Figure 11 20-year monthly average discharges in Citarum watershed

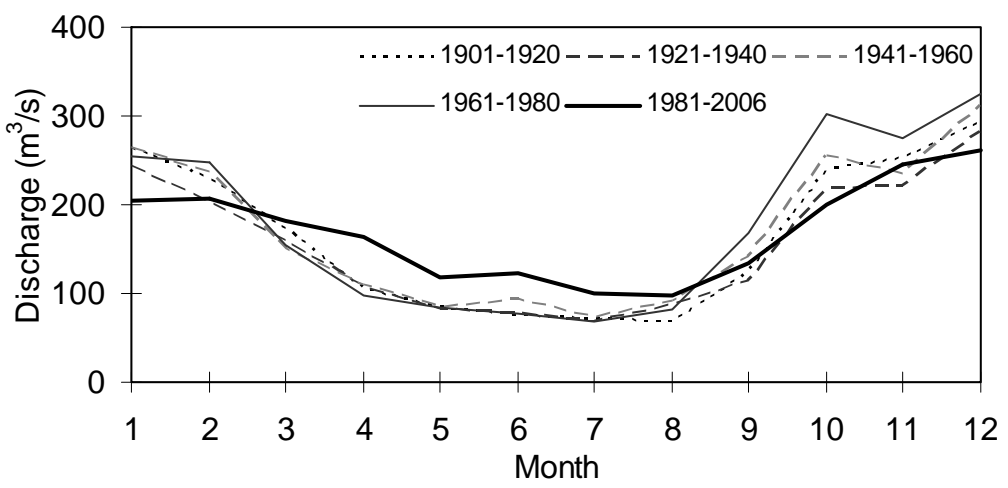

Figure 12 20-year monthly average discharges in Cimanuk watershed

Changes in simulated discharges relative to the first 20-year period are shown (Figure 13). Except for Ciujung, all watersheds show decreasing discharges during the second 20-year period (1921-1940). Except for Cimanuk, all discharges exhibit increasing trends from the 1941-1960 periods to the latest period (1981-2006). The relative changes noted for the latest 20year period compared to the first 20 -year period reflect the increasing trend ranging from $3 \%$ to $9 \%$.

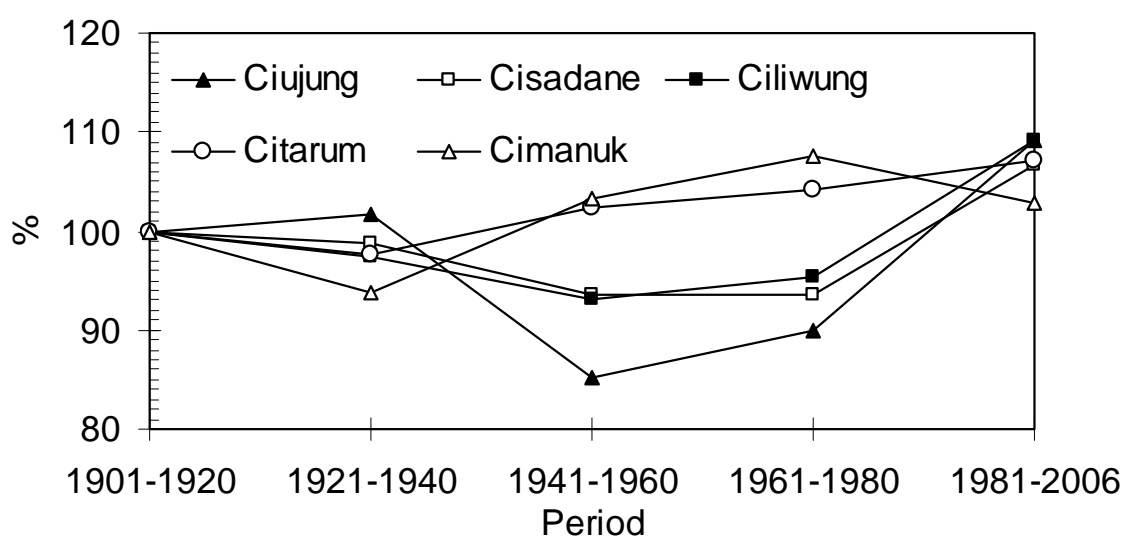

Figure 13 Changes of simulated discharges relative to the period of 1901-1920 (in \%) 


\section{CONCLUSION}

In this study, the $20^{\text {th }}$ century's river discharges of northwestern Java were simulated at a resolution of $100 \mathrm{~m} \times 100 \mathrm{~m}$. It was found that the average temperature has dramatically increased during the past century. Between 1901 and 2006, the average temperature increased by $1.12^{\circ} \mathrm{C}$. Related to land cover, significant reductions of the water holding capacity of the soil and the crop factor have been observed, especially in the latest decade of the simulation period. These changes can be attributed to decreased forest cover. Positive trends of simulated discharges were noted for all watersheds and periods. The most significant trend is seen in the 1990-2006 period. Monthly average discharges in the period of 1981-2006 is greater compared to the period $1901-1920$, by $3 \%$ to $9 \%$.

\section{ACKNOWLEDGEMENT}

The authors would like to thank The Ministry of National Education (Kementrian Pendidikan Nasional) for providing the Excellence Scholarship (Beasiswa Unggulan) of master double degree programme between Institute of Technology Bandung (ITB) and Chiba University for a collaborative master thesis project. The research was supported in part by a grant from the KNAW (Royal Netherlands Academy of Arts and Sciences) Mobility Programme (09-MP-10). Valuable discussions with Josaphat Tetuko Sri Sumantyo, Ph.D., Ivonne Milichristi Radjawane, Ph.D., Dr. Atsushi Higuchi and Ms. Friska Nur Afianti are acknowledged. This manuscript benefits from anonymous editors and reviewers.

\section{REFERENCES}

Aerts, J. C. J. H., Kriek, M., Schepel, M., 1999. STREAM, Spatial Tools for River Basins and Environment and Analysis of Management Options: 'Set Up and Requirements', Physics and Chemistry of the Earth Part B, 24(6), 591-595.

Julian, M. M., Poerbandono, Ward, P. J., 2009a. Simulation of the Latest Century's Discharges of Major Rivers of North-western Java to the Java Sea, Indonesia. In: Proceedings of International Seminar on Climate Change Impacts on Water Resources and Coastal Management in Developing Countries, 4-6 May 2009, Manado, Indonesia.

Julian, M.M., Poerbandono, Ward, P.J., 2009b. The Role of Precipitation, Temperature, and Land Cover in Controlling Run-off of the Northwest of Java Coastal Zones: A Climate Change Perspective. In: International Symposium: Effect of Climate Change on Coastal Management, 18-20 May 2009, Bandung, Indonesia.

Kwadijk, J.C.J., 1993. The Impact of Climate Change on the Discharge of the River Rhine, Ph.D. thesis, Universiteit Utrecht, Utrecht, The Netherlands, p. 201.

Oak Ridge National Laboratory Distributed Active Archive Center (ORNL DAAC), 2001. Available online at: <http://daac.ornl.gov/S2K/safari.html > from ORNL DAAC, Oak Ridge, Tennessee, U.S.A. [Accessed November 5, 2010].

Poerbandono, R., Ward, P.J., Julian, M.M., 2009a. Set Up and Calibration of a Spatial Tool for Simulating River Discharge of Western Java in Recent Decades: Preliminary Results and Assessments, ITB Journal on Engineering Science, Volume 41, No. 1, 50-64.

Poerbandono, Ward, P.J., Julian, M.M., Harto, A.B., 2009b. Spatial Simulation of Watershed Response Across Jakarta to the Prevailing Rainfall Climate According to Effective Enforcement of Perpres 54/2008. In: International Conference on Regional Development, Environment and Infrastructures "Trend, Issues and Challenges Confronting Regional Development, Infrastructure and Environment in Developing Countries", 18-19 June 2009, Bandung, Indonesia.

Poerbandono, Ward, P.J., Prijatna, K., Riqqi, A., Julian, M.M., 2009c. Spatio-temporal Assessment of Climate, Land Use and Water Balance using Spatial Tools. Case Study: 
West of Java, Indonesia. In: Proceedings of The $10^{\text {th }}$ South East Asian Survey Congress, $\mathrm{p}$. 317-325, 4-7 August 2009, Denpasar, Indonesia.

Thornthwaite, C.W., \& Mather, J.R., 1957. Instructions and Tables for Computing Potential Evapotranspiration and the Water Balance, Publications in Climatology, 10(3), 183-243.

University of East Anglia Climate Research Unit (CRU), 2008. CRU Datasets, British Atmospheric Data Centre, Available at: <http://badc.nerc.ac.uk/browse/badc/cru> .

Whitten, T., Soeriaatmadja, R.E., Afiff, S.A., 1996. The Ecology of Java and Bali, Periplus Editions, Dalhousie University.

Xiong, L., \& Guo, S., 2004. Trend Test and Change-point Detection for the Annual Discharge Series of the Yangtze River at the Yichang Hydrological Station, Hydrological Science Journal, 49(1), 99-112. 